\title{
Serum ferritin levels are associated with frequent consumption of iron- and ascorbate-rich foods among women of childbearing age in Nandi County, Kenya
}

\author{
Patrick Nyamemba Nyakundi* (1), Juliana Kiio and Ann Wambui Munyaka \\ Department of Food, Nutrition and Dietetics, Kenyatta University, Nairobi, Kenya
}

(Received 19 May 2021 - Final revision received 17 December 2021 - Accepted 20 December 2021)

Journal of Nutritional Science (2022), vol. 11, e6, page 1 of 8

doi:10.1017/jns.2022.5

Abstract

Information on consumption patterns of iron- and ascorbate-rich foods and their influence on iron status among women of childbearing age (WCA) is scarce in Kenya despite iron deficiency being rampant. The present study investigated consumption patterns of iron- and ascorbate-rich foods on iron status among WCA in Kapsabet Ward, Kenya. The study adopted a cross-sectional analytical design. A sample of 160 respondents was systematically selected proportionately in the eight villages. Consumption patterns of iron- and ascorbate-rich foods were assessed using a modified 7-d Food Frequency Questionnaire. Venous blood $(2 \mathrm{ml})$ was drawn from participants. Serum ferritin and C-reactive proteins were measured by enzyme immunoassay. Consumption patterns of iron- and ascorbate-rich foods were analysed using descriptive statistics. Multivariable regression was conducted to investigate the association between iron- and ascorbate-rich foods consumption and iron status. Confounding variables such as consumption of foods high phytate levels, milk and milk products, recent major blood losses and parasitic infections were controlled for during analysis. The prevalence of iron deficiency among the WCA was $45.0 \%$. Iron-rich foods were rarely $(<2$ times/week) consumed by the respondents with the majority reporting infrequent consumption: meat $(61.3 \%)$, sardines $(61.9 \%)$, oranges $(54.4 \%)$ and fortified breakfast cereals $(94.4 \%)$, except for kale and beans. Iron- (iron-fortified porridge, meat, sardines, beans, amaranth and spider plants) and ascorbate- (oranges and mangoes) rich foods positively predicted $(\mathrm{AOR}=4 \cdot 851, P=$ 0.021) the normal iron status of WCA. WCA should consume above 2 intakes per week of each iron- and ascorbate-rich food for better iron status outcomes.

Key words: Ascorbate-rich foods: Iron-rich foods: Serum ferritin: Women of childbearing age

\section{Introduction}

Twenty-one per cent of women of childbearing age (WCA) in Kenya are iron deficient ${ }^{(1)}$. Iron deficiency is associated with far-reaching consequences in human health, economic development and the social well-being of a population ${ }^{(2)}$. It is recorded to be a key contributor to 'the global burden of anaemia $^{\text {(3) }}$. Iron deficiency anaemia (IDA) affects maternal and fetal health adversely and is associated with elevated maternal and fetal mortality and morbidity. The affected women usually experience fainting, difficulties in sleeping, breathing difficulties, palpitations and tiredness ${ }^{(4)}$. Also, their risk of developing pre-eclampsia, haemorrhage, perinatal infections, behavioural difficulties and impaired post-partum cognitive functions is increased ${ }^{(5,6)}$. The negative perinatal outcomes suffered may include preterm babies, intrauterine retardation of growth and low birth weight with increased mortality risks ${ }^{(7)}$.

The most prevalent type of anaemia reported is IDA especially among $\mathrm{WCA}^{(8)}$. It is said to exist when blood has an inadequate supply of erythrocytes which is mainly caused by the lack of iron that is required for erythropoiesis ${ }^{(9)}$. Since, blood lacks enough erythrocytes, which are primarily engaged in the transportation of oxygen in the body, energy metabolism in cells is impaired leading to tiredness, extreme fatigue,

* Corresponding author: Nyakundi Patrick Nyamemba, email nyakundi.nyamemba@students.ku.ac.ke 
shortness of breath, cold feet and hands, pale skin, chest pain, brittle nails, inflammation of the tongue, headache, lightheadedness and poor appetite ${ }^{(8,10,11)}$. In WCA, factors that contribute to IDA include lack of food availability, inadequate dietary diversity, inadequate intake of dietary iron, consumption of poor diets, repeated pregnancies, short intervals between pregnancies and insufficient health systems ${ }^{(12)}$.

Studies conducted in Kenya among pregnant women report their dietary patterns to consist of mashed maize meal ${ }^{(13,14)}$ and sardines ${ }^{(14)}$. Overall, Kiboi et al. ${ }^{(13)}$, Smith ${ }^{(15)}$ and Waweru et al. ${ }^{(16)}$ reported that women's diets were deficient in iron-rich foods. Two Kenyan studies reported infrequent consumption of iron-rich foods among women ${ }^{(14,17)}$. Similarly, studies from Mumbai in India ${ }^{(18)}$ and both rural and urban areas of Bangladesh ${ }^{(19)}$ have reported a low intake of meat and meat products among WCA. The fact that animal products were generally unpopular among women could compound efforts of supplying sufficient iron to the women as animal products provide haeme iron that has higher bioavailability as compared to non-haeme iron ${ }^{(20)}$. Subsequently, intake of iron supplements and iron has been recorded to be inadequate among expectant women in thirdworld countries ${ }^{(15)}$.

Since the majority of third-world countries' women are reported to mainly consume plant-based foods, then strategizing to promote maximal absorption of non-haeme iron is pertinent. Ascorbic acid has been shown to promote the absorption of iron, especially non-haeme iron ${ }^{(21)}$. The ascorbate's enhancing effect can be credited to its ability to transform ferric iron $\left(\mathrm{Fe}^{3+}\right)$ to ferrous iron $\left(\mathrm{Fe}^{2+}\right)$ in the duodenum and stomach to 'form soluble complexes' in higher $\mathrm{pH}$ of the small intestines to enable its absorption ${ }^{(22)}$. Vegetables and fruits are the richest sources of natural ascorbic acid $^{(23)}$. Fruits rich in ascorbic acid include lemons, oranges, green pepper, papaya, oranges, kiwi, guavas and grapefruit ${ }^{(24)}$. Dark green leafy vegetables such as amaranth, spinach, broccoli, cauliflower, kale and spider plants are rich in natural vitamin $\mathrm{C}$. The seven most popular and readily available fruits in the Kenyan markets include mangoes, oranges, bananas, apples, pawpaws, pineapples and avocados ${ }^{(25)}$. Although most of the fruits in Kenya are seasonal, bananas, oranges and mangoes are readily available most of the time in the year ${ }^{(26)}$. A study conducted in western Kenya established that the favourite fruits among women were mangoes, avocados, oranges, sweet bananas and pawpaws ${ }^{(27)}$. Two Kenyan studies record a low intake of both fruits and vegetables among women way below the recommended level ${ }^{(27,28)}$. Similarly, a study conducted in rural India among women established that fruits were infrequently consumed and below the recommended amounts ${ }^{(29)}$. Many factors could influence the consumption of fruits including the seasonality of their production ${ }^{(26)}$, distribution channels ${ }^{(29)}$ and whether they are local or exotic as well as the price fluctuations.

However, there is a paucity of scientific research carried out in Kenya to understand the consumption pattern of iron- and ascorbate-rich foods. Thus, the present study investigated the consumption pattern of iron- and ascorbate-rich foods and its relationship with iron status among WCA in Nandi County.

\section{Methodology}

An analytical cross-sectional design was adopted to carry out the study among WCA in Nandi County, Kenya. The consumption pattern of iron- and ascorbate-rich foods were the independent variables whereas the iron status of WCA was the dependent variable. Women who were non-pregnant, non-lactating and aged between 15 and 49 years were included in the study. However, respondents who supplemented on iron regularly, recently donated blood (less than 6 months) or were ailing from chronic conditions were excluded from the study.

\section{Sample size determination and sampling technique}

G* Power software version 3.1.9.4 (Universität Düsseldorf, Germany) was used to determine the sample size. The power $(1-\beta)$ and significance $(\alpha)$ were set at 0.05 and 0.95 , respectively. The odds ratio for failing to reject the alternative hypothesis $((\operatorname{Pr}(y=1 \mid x=1)=\mathrm{H} 1)$ was 0.65 and OR for rejecting the null hypothesis $\left((\operatorname{Pr}(y=1 \mid x=1)=\mathrm{Ho})\right.$ was $0 \cdot 35^{(30)}$. Therefore, the sample size determined was 144 WCA. To account for incomplete questionnaires, $10 \%$ was added to make 160 respondents. Eight villages were determined from Kapsabet Ward by village divisions including Kibabet (9), Township (48), Chemundu (25), Kimonde (12), Kimindamugunya (10), Kiropretmeswo (19), Kimundi (17) and Goitebes (20). Proportionate samples were determined for each village and a systematic sampling technique was used to select participants from respective villages.

\section{Data collection tools and procedure}

A modified food frequency questionnaire (MFFQ) entailing 104 food items was used to collect the consumption patterns of iron- and ascorbate-rich foods. Ten per cent of the sample size $^{(31)}$ selected from Kapsabet Ward was used to conduct a pilot study. The finding of the pilot study informed the modification done on the data collection tool. The test-retest method was used to ensure the reliability of tools. Seven undergraduate nutrition students were recruited and trained on data collection procedures. Also, three qualified phlebotomists were recruited and trained on the blood collection process. Role-plays and demonstrations were used in training until the researcher was satisfied with the data collection competency of the interviewers. During the fieldwork, three teams, consisting of two or three interviewers and one phlebotomist, were dispatched to the assigned villages in Kapsabet Ward. Respondents were systematically selected and informed consent was obtained after which the MFFQ was filled by the interviewers. Blood from the respondents was obtained immediately after the filling of MFFQ.

\section{Collection of blood sample}

The phlebotomist disinfected skin using alcohol swabs. Then, $2 \mathrm{ml}$ of venous blood was collected. $1.5 \mathrm{ml}$ of the obtained blood was aliquoted into plain vacutainer tubes. The tubes were coded for identification and then packed in a cooler 
box $\left(15^{\circ} \mathrm{C}\right)$ and sent to Chepsoo Medical Centre for serum separation upon centrifugation. The separated serum was put into vials and refrigerated at $4^{\circ} \mathrm{C}$. The $5 \mathrm{~d}$ collected serum was packed in a cooler box at $15^{\circ} \mathrm{C}$ and transported to the University of Nairobi/KNH Paediatric laboratory and kept at a frozen state (below $-20^{\circ} \mathrm{C}$ ) until analysis to determine serum ferritin levels and $\mathrm{C}$-reactive protein (CRP). Repeated cycles of freezing and thawing were avoided to retain the sample integrity.

\section{Biochemical methods for determining serum ferritin}

'Elegance Amplified Enzyme-Linked Immunosorbent Assay (ELISA)' was used to quantitatively determine serum ferritin (SF). The determination was carried on LIASON ${ }^{\circledR}$ Analyser (DiaSorin S.p.A. - Saluggia - Italy) $^{(13,14)}$. CRP was analysed on HumaStar 600 machine (Wiesbaden, Germany) quantitatively by an immunoturbidimetric assay method. Human serum ferritin ELISA kits (Surgipath Services East Africa Ltd) and C-reactive protein ELISA kits (Chem Labs Ltd) and the standards were stored at a temperature of $2-8{ }^{\circ} \mathrm{C}$. During analysis, the serum samples were retrieved from storage, defrost, and thoroughly mixed using a vortex mixer before running the tests. Lipemic or grossly haemolysed samples, harbouring alien materials such as cotton wool, clotted or those amounting to below $160 \mu \mathrm{L}$ were altogether excluded from the analysis. However, none of the study's sample was eligible for exclusion. Participants were classified iron deficient (SF $<15 \mu \mathrm{g} / 1$ or SF $15-70$ $\mu \mathrm{g} / \mathrm{l}$ and CRP $>5 \mathrm{mg} / \mathrm{l}$ ) otherwise normal ferritin levels ${ }^{(32,33)}$.

\section{Data analysis}

Data on consumption patterns of iron- and ascorbate-rich foods and biomarkers were entered into SPSS software version 22 (Illinois, Chicago). Frequency and percentages were used to determine consumption patterns of iron- and ascorbate-rich foods. Multivariable regression was used to determine the association between consumption patterns of iron- and ascorbate-rich foods and iron status of WCA. A $P$-value of $<0.05$ was considered to be statistically significant. Confounding variables, such as parasitic infections and recent blood losses, were controlled for during analysis.

\section{Ethical considerations}

The study was conducted according to the guidelines laid down in the Declaration of Helsinki and all procedures involving human participants were approved by the Kenyatta University Ethics Review Committee (PKU/2029/11176). Written informed consent was obtained from all respondents. Confidentiality and privacy of the respondents were ensured throughout the data collection and processing. A research permit was sought from the National Commission of Science Technology and Innovation (NACOSTI/P/19/2975).

\section{Results}

Consumption of iron-rich foods among the study respondents

Table 1 shows the consumption patterns for iron-rich foods among study respondents. Most of the iron-fortified food products were infrequently consumed (i.e. $<2$ times/week) by the respondents; fortified breakfast cereals $(94.4 \%)$, fortified brown chapatti $(84.4 \%)$, fortified porridge $(57.5 \%)$ and fortified refined ugali $(53.8 \%)$. Meat $(61.3 \%)$, sardines $(61.9 \%)$, chicken $(80.0 \%)$ and tilapia $(82.5 \%)$ were infrequently consumed. Among good sources of non-haeme iron frequently consumed included kale $(76 \cdot 3 \%)$ and beans $(50 \cdot 6 \%)$. However, most of the foods rich in non-haeme iron were infrequently consumed (i.e. $<2$ times/week); kunde and mrenda (cowpeas and jute mallow leaves) $(79.4 \%)$, kunde $(77.5 \%)$, terere (amaranth) (77.5\%), nderema (vine spinach) (76.3\%), pumpkin leaves $(73.1 \%)$, saget (spider plant) $(68 \cdot 8 \%)$, green grams $(66.9 \%)$, spinach $(66.9 \%)$ and mrenda $(63.1 \%)$.

\section{Consumption of ascorbate-rich foods among WCA}

Vegetables including spinach, kale, spider plant (Table 1) cabbages and capsicum (Table 2), and most fruits are considered

Table 1. Frequency of food consumption patterns of the study respondents

\begin{tabular}{|c|c|c|}
\hline \multirow{2}{*}{ Characteristics } & \multicolumn{2}{|c|}{$n 160$} \\
\hline & $\begin{array}{c}\text { Infrequently }(<2 \\
\text { times/week) }(n(\%))\end{array}$ & $\begin{array}{c}\text { Frequently ( } \geq 2 \text { times/ } \\
\text { week) }(n(\%))\end{array}$ \\
\hline \multicolumn{3}{|l|}{ Cereals and their products } \\
\hline $\begin{array}{l}\text { Iron-fortified Porridge } \\
\text { flour (mixture) }\end{array}$ & $92(57.5 \%)$ & $68(42.5 \%)$ \\
\hline Unrefined ugali flour & $77(48.1 \%)$ & $83(51.9 \%)$ \\
\hline $\begin{array}{l}\text { Iron-fortified refined } \\
\text { ugali }\end{array}$ & $86(53.8 \%)$ & $74(46 \cdot 3 \%)$ \\
\hline $\begin{array}{l}\text { Iron-fortified brown } \\
\text { chapatti }\end{array}$ & $125(84.4 \%)$ & $25(15 \cdot 6 \%)$ \\
\hline $\begin{array}{l}\text { Iron-fortified } \\
\text { breakfast cereals }{ }^{a}\end{array}$ & $151(94.4 \%)$ & $9(5.6 \%)$ \\
\hline \multicolumn{3}{|l|}{ Meat and meat products } \\
\hline Meat & $98(61.3 \%)$ & $62(38.7 \%)$ \\
\hline Beef Samosa & $145(90 \cdot 6 \%)$ & $15(9.4 \%)$ \\
\hline Chicken & $128(80.0 \%)$ & $32(20.0 \%)$ \\
\hline Sausages & $138(86.3 \%)$ & $22(13.8 \%)$ \\
\hline Tilapia & $132(82.5 \%)$ & $28(17.5 \%)$ \\
\hline Sardines & $99(61.9 \%)$ & $61(38.1 \%)$ \\
\hline \multicolumn{3}{|l|}{ Legumes and Pulses } \\
\hline Green grams & $107(66.9 \%)$ & $53(33.1 \%)$ \\
\hline Beans & $79(49.4 \%)$ & $81(50.6 \%)$ \\
\hline \multicolumn{3}{|l|}{ Green leafy vegetable } \\
\hline Terere (amaranth) & $124(77.5 \%)$ & $36(22.5 \%)$ \\
\hline Kale & $38(23.8 \%)$ & $122(76 \cdot 3 \%)$ \\
\hline Mrenda (jute mallow) & $101(63.1 \%)$ & $59(36.9 \%)$ \\
\hline Pumpkin leaves & $117(73.1 \%)$ & $43(26.9 \%)$ \\
\hline Saget (Spider plant) & $110(68.8 \%)$ & $50(31.3 \%)$ \\
\hline $\begin{array}{l}\text { Nderema (Vine } \\
\text { Spinach) }\end{array}$ & $122(76 \cdot 3 \%)$ & $38(23.8 \%)$ \\
\hline Spinach & $107(66.9 \%)$ & $53(33.1 \%)$ \\
\hline $\begin{array}{l}\text { Kunde (Cowpeas } \\
\text { leaves) }\end{array}$ & $124(77.5 \%)$ & $36(22.5 \%)$ \\
\hline Kunde and $m r e n d a^{\mathrm{b}}$ & $127(79.4 \%)$ & $33(20.6 \%)$ \\
\hline
\end{tabular}

a Iron-fortified breakfast cereals, i.e. cornflakes and Weetabix.

${ }^{\mathrm{b}}$ Kunde and mrenda (Cowpeas and jute mallow leaves). 
Table 2. Consumption of ascorbate-rich foods among the study respondents (fruits)

\begin{tabular}{|c|c|c|c|c|c|}
\hline \multirow[b]{2}{*}{ Characteristics } & \multicolumn{4}{|c|}{ 7-d Food Intake Frequencies (n 160) } & \multirow{2}{*}{$\begin{array}{c}\text { Frequently } \\
(\geq 2 \text { times/week) }\end{array}$} \\
\hline & Never $n(\%)$ & 1 time/week $n(\%)$ & 2-4 times/week $n(\%)$ & 5-7 times/week $n(\%)$ & \\
\hline \multicolumn{6}{|l|}{ Fruits } \\
\hline Oranges & $41(25.6 \%)$ & $46(28.8 \%)$ & $53(33.1 \%)$ & $20(12.5 \%)$ & $73(45.6 \%)$ \\
\hline Lemons & $118(73 \cdot 8 \%)$ & $22(13 \cdot 8 \%)$ & $16(10 \cdot 0 \%)$ & $4(2.5 \%)$ & $20(12.5 \%)$ \\
\hline Orange juice & $128(80 \cdot 0 \%)$ & $15(9.4 \%)$ & $14(8.8 \%)$ & $3(1.9 \%)$ & $17(10 \cdot 6 \%)$ \\
\hline Pineapples & $104(65 \cdot 0 \%)$ & $25(9.4 \%)$ & $23(14.4 \%)$ & $8(5.0 \%)$ & $31(19.4 \%)$ \\
\hline Guavas & $125(78 \cdot 1 \%)$ & $23(14.4 \%)$ & $9(5.6 \%)$ & $3(1.9 \%)$ & $12(7.5 \%)$ \\
\hline Pawpaws & $128(80 \cdot 0 \%)$ & $15(9.4 \%)$ & $10(6 \cdot 3 \%)$ & $7(4.4 \%)$ & $17(10 \cdot 6 \%)$ \\
\hline Apples & $113(70 \cdot 6 \%)$ & $26(16.3 \%)$ & $16(10.0 \%)$ & $5(3.1 \%)$ & $21(13.1 \%)$ \\
\hline Mango & $34(21.3 \%)$ & $64(40.0 \%)$ & $50(31.3 \%)$ & $12(7.5 \%)$ & $62(38.8 \%)$ \\
\hline Avocado & 77 (48.1\%) & $33(20.6 \%)$ & $24(15.0 \%)$ & $26(16.3 \%)$ & $50(31.3 \%)$ \\
\hline Grapes & $123(76.9 \%)$ & $12(7.5 \%)$ & $13(8.1 \%)$ & $12(7.5 \%)$ & 25 (15.6 \%) \\
\hline Banana & $45(28.1 \%)$ & $38(23.8 \%)$ & $47(29.4 \%)$ & $30(18.8 \%)$ & 77 (48.1\%) \\
\hline Watermelon & $96(60.0 \%)$ & $25(15 \cdot 6 \%)$ & $18(11.3 \%)$ & $21(13.1 \%)$ & 39 (24.4 \%) \\
\hline \multicolumn{6}{|l|}{ Vegetables } \\
\hline Capsicum & $126(78 \cdot 8$ \%) & $12(7.5 \%)$ & $16(10.0 \%)$ & $6(3.8 \%)$ & $22(13.8 \%)$ \\
\hline Cucumber & $121(75.6 \%)$ & $9(5.6 \%)$ & $22(13.8 \%)$ & $8(5.0 \%)$ & $30(18.8 \%)$ \\
\hline
\end{tabular}

to be a good source of ascorbate. The most frequently consumed fruits included bananas $(48.1 \%)$, oranges $(45.6 \%)$, mangoes $(38 \cdot 8 \%)$ and avocados $(31 \cdot 3 \%)$.

\section{Deworming, malaria and recent blood loss status of the respondents}

Over half of the study respondents $(51 \cdot 1 \%)$ dewormed regularly (Table 3). Nearly all of the respondents (98.9\%) had not experienced an episode of malaria 2 weeks preceding the data collection. Among those who had major blood loss, $3 \cdot 1 \%$ of them experienced major blood loss within the previous 3 months before the study data collection.

\section{Serum ferritin levels of the respondents}

After the adjustment of serum ferritin concentrations for inflammation (CRP $>5 \mathrm{mg} / \mathrm{l}$ ), $45 \%$ of the respondents were observed to be iron deficient (SF $<15 \mu \mathrm{g} / 1$ or SF $15-70 \mu \mathrm{g}$ ) 1 and CRP $>5 \mathrm{mg} / \mathrm{l}$ ) (Table 4).

\section{Association between ascorbate-rich foods consumption and iron status among study respondents}

To control for confounding variables, seven respondents were excluded from the logistic regression. Out of these seven, four

Table 3. Deworming, malaria and recent blood loss status of the study respondents

\begin{tabular}{lc}
\hline Characteristics & $n(\%)$ \\
\hline Frequency of deworming $(n 94)$ & \\
$\quad$ Regularly (every 3 months) & $48(51.1 \%)$ \\
$\quad$ Irregularly & $46(48.9 \%)$ \\
Frequency of malaria episodes ( $n$ 160) & \\
$\quad$ Never & $60(37.5 \%)$ \\
Before 2 weeks of data collection & $97(60.6 \%)$ \\
$\quad$ Within 2 weeks preceding the data collection & $3(1.9 \%)$ \\
Had recent (<3 months) major blood loss & $5(3.1 \%)$ \\
\hline
\end{tabular}

had recent major blood loss and two had a frequent episode of malaria whereas one had both (Table 4). The association between consumption of ascorbate-rich foods and iron status is presented in Table 5. Respondents who consumed oranges 2-4 times/week had three times more chances of having normal iron status as compared to those who did not $(\mathrm{AOR}=$ $3 \cdot 233, P=0 \cdot 009)$. Increasing the consumption of oranges to more than 5 times/week resulted in an elevated likelihood of fifteen $(\mathrm{AOR}=15 \cdot 283, P=0.001)$ of having normal iron status. Consuming mangoes 2-4 times/week gave the respondents six times higher chances of normalising their iron status (AOR $=5.960, P<0.001)$ whereas increasing the consumption to more than 5 times/week elevated the likelihood to nearly twenty-two (AOR $=21 \cdot 750, P=0 \cdot 006)$.

\section{Association between iron-rich foods consumption and iron status among the respondents}

Respondents who used mixed porridge flour (millet, sorghum and/or cassava) once/week were four times (AOR $=4 \cdot 249, P$ $=0.006)$ more likely to have normal iron stores whereas those that used it 2-4 times/week had nineteen times (AOR = $18.592, P<0 \cdot 001$ ) higher likelihood (Table 6). Meat consumption was a statistically significant predictor of iron status demonstrated in the respondents who consumed meat once/week being three times more likely to have normal iron stores $(\mathrm{AOR}=2 \cdot 658, P=0 \cdot 016)$. However, the likelihood increased significantly to four among those who reported consuming meat 2-4 times/week (AOR $=4.450, P<0 \cdot 001)$. The consumption of sardines was demonstrated to significantly predict iron status. Women who subsisted on sardines once/ week had seven times more chances (AOR $=7 \cdot 365, P<$ $0 \cdot 001$ ) of having normal iron status whereas those who consumed it 2-4 times/week had nine times higher chances (AOR $=8 \cdot 814, \quad P<0 \cdot 001$ ). Consuming beans once/week increased the likelihood of the women having normal iron status by four $(\mathrm{AOR}=4 \cdot 173, P=0 \cdot 007)$. The likelihood increased to nearly six times for those who consumed beans 
Table 4. Iron status of study respondents

\begin{tabular}{|c|c|}
\hline Iron status indicators & $n 160(n(\%))$ \\
\hline \multicolumn{2}{|l|}{ Inflammation marker } \\
\hline \multicolumn{2}{|l|}{ C-reactive protein (CRP) levels (mg/l) } \\
\hline Range of CRP levels (mg/l) & $2 \cdot 9-14 \cdot 8$ \\
\hline Mean [SD] & $5 \cdot 0[2 \cdot 1]$ \\
\hline Elevated levels $(\mathrm{CRP}>5 \mathrm{mg} / \mathrm{l})$ & $49(30.6 \%)$ \\
\hline \multicolumn{2}{|l|}{ Serum Ferritin (SF) levels $(\mu \mathrm{g} / \mathrm{l})$} \\
\hline Range of SF levels $(\mu \mathrm{g} / \mathrm{l})$ & $5 \cdot 4-323$ \\
\hline Mean (SD) & $35 \cdot 3[42 \cdot 2]$ \\
\hline Crude Iron depleted stores (SF $<15 \mu \mathrm{g} / \mathrm{l})$ & $34(21.3 \%)$ \\
\hline SF $15-70 \mu \mathrm{g} / \mathrm{l}$ and $\mathrm{CRP}>5 \mathrm{mg} / \mathrm{l}$ & $38(23.8 \%)$ \\
\hline \multicolumn{2}{|l|}{ Adjusted $^{\mathrm{a}}$ iron stores status } \\
\hline $\begin{array}{l}\text { Iron deficient (ID) (SF }<15 \mu \mathrm{g} / \mathrm{l} \text { or SF } 15-70 \mu \mathrm{g} / \mathrm{l} \text { and } \\
\mathrm{CRP}>5 \mathrm{mg} / \mathrm{l}\end{array}$ & $72(45 \cdot 0 \%)$ \\
\hline
\end{tabular}

${ }^{\text {a }}$ Adjusted iron stores for inflammation.

2-4 times/week $(\mathrm{AOR}=6.053, P<0.001)$ and to thirteen times if the women consumed beans more than 5 times/ week $(\mathrm{AOR}=12 \cdot 926, P=0 \cdot 005)$ (Table 6).

The association between the consumption of dark green leafy vegetables and iron status of respondents is presented in Table 7. Respondents who consumed amaranth once/ week had 2.5 times higher chances (AOR $=2.534 P=$ $0 \cdot 019)$ of having normal iron stores whereas those who consumed it 2-4 times/week had seven times higher chances (AOR $=7 \cdot 141, P=0 \cdot 001$ ). The likelihood increased to nine times if the respondents consumed amaranth more than 5 times/week $(\mathrm{AOR}=8 \cdot 818, P=0 \cdot 008)$. Consuming spider plants once/week gave the respondents three times higher chances $(\mathrm{AOR}=3 \cdot 290, \quad P=0.007)$ of developing normal iron stores as compared to those who never took the vegetable. Increasing the intake of spider plants to 2-4 times/ week elevated the likelihood to twenty-two of having normal iron stores $(\mathrm{AOR}=22 \cdot 132, P<0 \cdot 001)($ Table 7$)$.

\section{Discussion}

The study found that iron deficiency prevalence was at $45 \%$ among the study respondents. The observed prevalence is more than double of the national iron deficiency prevalence reported to be $21.3 \%$ in $2011^{(1)}$. The high prevalence in the study area suggests the prevailing of unique determinants that explain the phenomena. Many factors determine the iron status of WCA, however, the present study investigated the consumption patterns of iron- and ascorbate-rich foods as a determinant.

The study found that an increase in the consumption of meat, sardines, fortified mixed porridge, beans, amaranth and spider plants significantly increased the likelihood of respondents having normal iron status. Meat and sardines ${ }^{(24)}$ are a rich source of haeme iron. A big advantage posed by taking haeme iron is that it is highly bioavailable ${ }^{(34)}$ and enhances the absorption of non-haeme iron ${ }^{(35)}$. Several studies have reported a significant dependency of iron status on haeme iron among women ${ }^{(36,37)}$ or meat intake ${ }^{(36,38-40)}$. Contrary, some studies found no association between meat intake and iron status among young women ${ }^{(23,41)}$. However, most of the respondents infrequently consumed meat probably due to its high cost. Similarly, Kenyan women have been noted to consume chicken and meat less frequently ${ }^{(13,16,17)}$. A study conducted in Mumbai among WCA found that the average intake of meat and their products were low ${ }^{(18)}$. The fact that animal products were generally unpopular among women could compound efforts of supplying sufficient iron to the women's body as animal products provide haeme iron that has higher bioavailability as compared to non-haeme iron $^{(20)}$.

Dark green leafy vegetables are a good source of non-haeme iron ${ }^{(24)}$. Only kale was frequently consumed vegetable. A Kenyan study reported that vegetables were poorly consumed

Table 5. Association between consumption of ascorbate-rich foods and iron status ${ }^{\mathrm{a}}$ among study participants

\begin{tabular}{|c|c|c|c|c|}
\hline Determinants & $n 153 \mathrm{AOR}[\mathrm{Cl}]^{\mathrm{b}}$ & $P^{\star}$ & Mean (SD) & $\mathrm{Cl}(95 \%)$ \\
\hline \multicolumn{5}{|l|}{ Oranges } \\
\hline Never (ref) & & 0.004 & $23.541(15.051)$ & $19 \cdot 017-28 \cdot 825$ \\
\hline 1 time/week & $2.265[0.906-5.659]$ & 0.080 & 34.609 (61.643) & $21 \cdot 017-28 \cdot 825$ \\
\hline 2-4 times/week & $3.233[1.338-7 \cdot 809]$ & 0.009 & $39.879(35.606)$ & $30.919-50.518$ \\
\hline 5-7 times/week & $15 \cdot 283$ [3.029-77.115] & 0.001 & $55.237(37.385)$ & $39 \cdot 293-72 \cdot 704$ \\
\hline \multicolumn{5}{|l|}{ Pineapples } \\
\hline Never (ref) & & 0.108 & $32.899(28.513)$ & $27 \cdot 798-38 \cdot 229$ \\
\hline 1 time/week & $0.511[0.208-1.254]$ & 0.143 & $27 \cdot 860$ 919.984) & $20 \cdot 400-35 \cdot 545$ \\
\hline 2-4 times/week & $1.629[0.606-4.373]$ & 0.333 & $58.945(88 \cdot 763)$ & $30 \cdot 709-104.792$ \\
\hline 5-7 times/week & $5 \cdot 019[0.588-42 \cdot 873]$ & 0.140 & $41 \cdot 775(38 \cdot 647)$ & $21 \cdot 971-70 \cdot 477$ \\
\hline \multicolumn{5}{|l|}{ Guavas } \\
\hline Never (ref) & & 0.691 & $33 \cdot 815(31.006)$ & $28 \cdot 723-39 \cdot 900$ \\
\hline 1 time/week & $0.712[0.061-8.271]$ & 0.786 & $50.595(85.333)$ & $26 \cdot 438-94 \cdot 675$ \\
\hline 2-4 times/week & $1.273[0.096-16.971]$ & 0.855 & $29 \cdot 478(22 \cdot 746)$ & $15 \cdot 853-45 \cdot 962$ \\
\hline 5-7 times/week & $0.666[0.043-10.393]$ & 0.772 & $49.733(32.458)$ & $25 \cdot 900-86.700$ \\
\hline \multicolumn{5}{|l|}{ Mango } \\
\hline Never (ref) & & $<0.001$ & $31.837(34.555)$ & $21.423-47.059$ \\
\hline 1 time/week & $1.662[0.677-4.081]$ & 0.268 & $25.358(20.851)$ & $20 \cdot 753-31 \cdot 228$ \\
\hline 2-4 times/week & 5.960 [5.960-15.936] & $<0.001$ & $40 \cdot 628(25 \cdot 354)$ & $33.493-47.946$ \\
\hline 5-7 times/week & $21.750[2.457-192.525]$ & 0.006 & $83.775(116.531)$ & $30 \cdot 955-162 \cdot 800$ \\
\hline
\end{tabular}

a The iron status indicator was serum ferritin levels.

${ }^{\mathrm{b}}$ Adjusted for parasitic infections, major blood losses, and milk and milk products.

* Significance level at $P<0.05$. 
Table 6. Association between iron-rich foods consumption and iron status ${ }^{a}$ among study respondents

\begin{tabular}{|c|c|c|c|c|}
\hline Determinants & $n 153 \mathrm{AOR}[\mathrm{Cl}]^{\mathrm{b}}$ & $P^{\star}$ & Mean (SD) & $\mathrm{Cl}(95 \%)$ \\
\hline \multicolumn{5}{|c|}{ Fortified Porridge flour (mixture) } \\
\hline Never (ref) & & $<0.001$ & $16.329(11.363)$ & $12 \cdot 807-20.553$ \\
\hline Once/week & $4.249[1.789-13.156]$ & 0.006 & $24.019(13.467)$ & $20 \cdot 935-28 \cdot 191$ \\
\hline 2-4 times/week & $18.592[12.92-230.518]$ & $<0.001$ & $58.413(66.887)$ & $42.070-78.959$ \\
\hline 5-7 times/week & $45.390[8.216-250.772]$ & $<0.001$ & $50.855(31.137)$ & $37.879-64.546$ \\
\hline \multicolumn{5}{|l|}{ Chicken } \\
\hline Never (ref) & & 0.481 & $37.051(52.947)$ & $27 \cdot 392-52 \cdot 019$ \\
\hline Once/week & $0.595[0.308-1.463]$ & 0.179 & $34.325(31.352)$ & $26 \cdot 280-43 \cdot 139$ \\
\hline 2-4 times/week & $0.835[0.328-2.090]$ & 0.693 & $38.407(35.745)$ & $26.998-52.588$ \\
\hline 5-7 times/week & $0.289[0.071-9.925]$ & 0.324 & $32.567(12 \cdot 661)$ & $19.600-44.900$ \\
\hline \multicolumn{5}{|l|}{ Meat } \\
\hline Never (ref) & & $<0.001$ & $20 \cdot 194(22.532)$ & $14 \cdot 975-27 \cdot 372$ \\
\hline Once/week & $2 \cdot 658[1 \cdot 882-9 \cdot 787]$ & 0.016 & $30.597(23.097)$ & $24 \cdot 997-36 \cdot 926$ \\
\hline 2-4 times/week & $4.410[4.450-41.727]$ & $<0.001$ & $57 \cdot 824(64 \cdot 329)$ & $42 \cdot 190-79 \cdot 584$ \\
\hline \multicolumn{5}{|l|}{ Sardines } \\
\hline Never (ref) & & $<0.001$ & $20.633(21.343)$ & $15 \cdot 328-26 \cdot 954$ \\
\hline Once/week & 7.365 [2.971-19.494] & $<0.001$ & $21.896(9.965)$ & $19 \cdot 218-25 \cdot 090$ \\
\hline 2-4 times/week & $8.814[6.690-63.511]$ & $<0.001$ & $43.809(24.948)$ & $37.514-52.038$ \\
\hline \multicolumn{5}{|l|}{ Beans } \\
\hline Never (ref) & & 0.002 & $21.597(17 \cdot 123)$ & $15 \cdot 633-27 \cdot 957$ \\
\hline Once/week & $4.173[1.514-10.843]$ & 0.007 & $32.971(31.352)$ & $25 \cdot 077-42 \cdot 234$ \\
\hline 2-4 times/week & $6.053[2 \cdot 850-20.028]$ & $<0.001$ & $42 \cdot 130(54.982)$ & $31.272-57.996$ \\
\hline 5-7 times/week & $12 \cdot 926$ [2.192-182.442] & 0.005 & $56 \cdot 210(40 \cdot 651)$ & $34.712-81.899$ \\
\hline
\end{tabular}

a The iron status indicator was serum ferritin levels.

${ }^{\mathrm{b}}$ Adjusted for parasitic infections, major blood losses, and milk and milk products.

* Significance level at $P<0.05$.

with women mostly subsisting on kale, which they ate 4 times/ week $^{(14)}$. Similarly, poor consumption of vegetables has been reported in Bangladesh ${ }^{(19)}$ and in third-world countries ${ }^{(15)}$. A high intake of beans was observed among the respondents, which is in line with the finding of previous Kenyan studies among women ${ }^{(13,16)}$. Plant-based food products are noted to supply non-haeme iron that, unfortunately, is not readily available for absorption especially when bioactive phenolic compounds such as tannins are present ${ }^{(20)}$. However, the absorption of non-haeme iron can be enhanced by not only

Table 7. Association between dark green leafy vegetable consumption and iron status ${ }^{a}$ among study respondents

\begin{tabular}{|c|c|c|c|c|}
\hline Determinants & $n 153 \mathrm{AOR}[\mathrm{Cl}]^{\mathrm{b}}$ & $P^{\star}$ & Mean (SD) & $\mathrm{Cl}(95 \%)$ \\
\hline \multicolumn{5}{|l|}{ Amaranth } \\
\hline Never (ref) & & 0.001 & $34.199(54.241)$ & $23 \cdot 891-49 \cdot 283$ \\
\hline Once/week & $2.534[1.166-5.507]$ & 0.019 & $28.102(24.498)$ & $22 \cdot 257-36 \cdot 212$ \\
\hline 2-4 times/week & $7 \cdot 141[2.153-23.688]$ & 0.001 & $41.930(24.763)$ & $32 \cdot 586-52 \cdot 349$ \\
\hline 5-7 times/week & $8 \cdot 818[1 \cdot 766-42 \cdot 044]$ & 0.008 & $67.585(40 \cdot 871)$ & $46 \cdot 028-90 \cdot 643$ \\
\hline \multicolumn{5}{|l|}{ Kale } \\
\hline Never (ref) & & 0.348 & $21.980(10.326)$ & $15 \cdot 835-27 \cdot 819$ \\
\hline Once/week & $2.888[0.606-13.762]$ & 0.183 & $51.515(82.9161)$ & $27 \cdot 192-88 \cdot 016$ \\
\hline 2-4 times/week & $3.691[0.878-15.524]$ & 0.075 & $33.813(29.032)$ & $27 \cdot 608-40 \cdot 625$ \\
\hline 5-7 times/week & $2.835[0.637-12.613]$ & 0.171 & $34.277(26.278)$ & $26 \cdot 779-43 \cdot 110$ \\
\hline \multicolumn{5}{|l|}{ Jute mallow } \\
\hline Never (ref) & & 0.832 & $26.918(22 \cdot 384)$ & $21.979-33.649$ \\
\hline Once/week & $1.138[0.498-2.599]$ & 0.760 & $47.364(70.938)$ & $29 \cdot 520-72 \cdot 947$ \\
\hline 2-4 times/week & $1.636[0.710-3.767]$ & 0.247 & $39.328(32.379)$ & $30 \cdot 902-49 \cdot 217$ \\
\hline 5-7 times/week & $2.290[0.557-9.415]$ & 0.251 & $32.325(15.115)$ & $24.076-41.358$ \\
\hline \multicolumn{5}{|l|}{ Spider plant } \\
\hline Never (ref) & & $<0.001$ & $25 \cdot 840(25 \cdot 738)$ & $19 \cdot 115-34 \cdot 417$ \\
\hline Once/week & $3.290[1.395-7.756]$ & 0.007 & $26.792(17.009)$ & $22 \cdot 713-31 \cdot 173$ \\
\hline 2-4 times/week & $22 \cdot 132[6 \cdot 831-71 \cdot 708]$ & $<0.001$ & $57.715(70.575)$ & $39.105-83.983$ \\
\hline 5-7 times/week & $21 \cdot 855[2 \cdot 379-200 \cdot 815]$ & 0.006 & $54.988(19.123)$ & $41 \cdot 300-68 \cdot 400$ \\
\hline \multicolumn{5}{|l|}{ Spinach } \\
\hline Never (ref) & & 0.382 & $41.530(56 \cdot 215)$ & $30 \cdot 723-55.544$ \\
\hline Once/week & $0.521[0.219-1.241]$ & 0.141 & $35.974(29.676)$ & $25 \cdot 789-47 \cdot 676$ \\
\hline 2-4 times/week & $0.699[0.301-1.623]$ & 0.405 & $29.600(26.757)$ & $22 \cdot 314-38 \cdot 846$ \\
\hline 5-7 times/week & $1.297[0.877-1.917]$ & 0.964 & $28.940(17.233)$ & $21 \cdot 281-38 \cdot 833$ \\
\hline
\end{tabular}

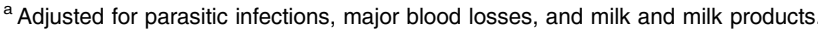

${ }^{\mathrm{b}}$ The iron status indicator was serum ferritin levels.

* Significance level at $P<0.05$. 
the endogenous ferrireductase but also by exogenous reducing agents such as ascorbic acid ${ }^{(42)}$.

Ascorbic acid is a powerful enhancer of iron absorption $^{(42,43)}$. Its mechanism is well-understood as it converts ferric iron to ferrous iron in the gastrointestinal tract to constitute soluble complexes at the low $\mathrm{pH}$ of the gastric section to enable iron absorption ${ }^{(22)}$. Vegetables and fruits are rich sources of natural ascorbic acid ${ }^{(23)}$ and, therefore, their consumption is very significant in enhancing iron absorption. The present study found out that an increase in the consumption of oranges and mangoes gave the respondents a correspondingly high likelihood of having normal iron status. These two fruits together with bananas were the most consumed by the respondents. Their consumption is encouraged because they are readily available in the Kenyan market alongside apples, pawpaws, pineapples and avoca$\operatorname{dos}^{(25-27)}$. Therefore, the consumption of oranges, mangoes, avocados and apples was more likely to be affected by price fluctuations rather than by seasonality.

However, infrequent consumption was registered among orange juices, pineapples, guavas, apples, watermelon, grapes and avocados. Many factors could influence the consumption of fruits including seasonality of their production ${ }^{(26)}$, distribution channels ${ }^{(29)}$, and whether they are local or exotic as well as the price fluctuations. Similarly, Kenyan studies have unfortunately reported low consumption of fruits among women $^{(16,27)}$. An Indian study also reported that rural women eat fruits infrequently and below the recommended level ${ }^{(29)}$. The fact that most of the respondents infrequently consumed these fruits could explain why they did not predict their iron status.

Studies have reported a positive association between dietary ascorbic acid ${ }^{(36,44)}$, fruits ${ }^{(36,45,46)}$ and fruit juices ${ }^{(45)}$ intake and iron status among WCA. However, the majority of the previous studies have reported no association between iron status among young women and overall intake of ascorbic $\operatorname{acid}^{(23,37,38,47,48)}$, intake of fruits ${ }^{(23,37,47,48)}$ or fruit juices ${ }^{(23,42)}$. Possible explanations for no association between ascorbaterich foods and iron status reported by most studies may include poor preparation practices and timing of fruits, method of cooking vegetables and frequency of consumption.

The study has limitations in that it did not assess the nutritional knowledge on the consumption of iron- and ascorbaterich foods among the respondents. Nutritional knowledge may confound the relationship between dietary patterns and iron status among the respondents. Another limitation of the study is that it did not determine chronic inflammation among the respondents to allow for correction of iron status based on levels of serum ferritin. Also, the study included age 15 women who are under adolescence and predisposed to suffer from the triple burden of iron-deficient anaemia.

\section{Conclusion}

The present study investigated the relationship between consumption patterns of iron- and ascorbate-rich foods and iron status among WCA. Four to five in every ten WCA in Nandi County were iron depleted. The respondents infrequently consumed iron- and ascorbate-rich foods. Consumption patterns of iron-rich foods (iron-fortified porridge, meat, sardines, beans, amaranth and spider plants) positively predicted the normal iron status of WCA. Ascorbate-rich foods (oranges and mangoes) consumption positively predicted the iron status of WCA. For better iron status outcome, WCA and other risk groups should consume at least 2 times/ week of each food rich in iron and ascorbate, i.e. meat and meat products, fortified food products, citrus fruits and dark green vegetables.

\section{Acknowledgements}

I recognise the steadfast and worthwhile financial and moral support supplied throughout my study by Dr Patrick Nyamemba Tumbo, family and friends.

The research received no specific grant from any funding agency, commercial or not-for-profit sectors. Also, the study did not receive any support in kind from any industry. The study design, analysis and writing of this article were not influenced in any way by industries or funders.

The first author (corresponding author) carried this research in the capacity of a postgraduate student at Kenyatta University. He was the principal investigator. The second and third authors played a supervisory role in the entire research process.

The authors declared that they have no conflict of interest.

\section{References}

1. KNBS (2011) The Kenya National Micronutrient Survey.

2. Lorena A (2013) The economic impact of anaemia in Peru. Ann Nutr Metab 63, 231.

3. WHO (2015) The Global Prevalence of Anaemia in 2011 [Internet], pp. 1-43. Available at www.who.int [cited 14 May 2019].

4. Lee KA, Zaffke ME \& Baratte-Beebe K (2002) Restless legs syndrome and sleep disturbance during pregnancy: the role of folate and iron. J Womens Health Gend Based Med 10, 335-341.

5. Milman N (2012) Postpartum anemia II: prevention and treatment. Ann Hematol 91, 143-154.

6. Murray-Kolb LE (2013) Iron and brain functions. Curr Opin Clin Nutr Metab Care 16, 703-707.

7. Abu-Ouf NM \& Jan MM (2015) The impact of maternal iron deficiency and iron deficiency anemia on child's health. Saudi Med J 36, 146.

8. Solovyova AV, Gace V, Ermolenko KS, et al. (2018) Anemia in women of reproductive age. In Current Topics in Anemia [Internet]. Available at file:///C:/Users/ADMIN/Downloads/57666.pdf [cited 19 April 2019].

9. Higgins JM (2015) Red blood cell population dynamics. Clin Lab Med 35, 43-57.

10. Black RE, Victora CG, Walker SP, et al. (2013) Maternal and child undernutrition and overweight in low-income and middle-income countries. Lancet (London, England) 382, 427-451.

11. Grieger J \& Clifton V (2014) A review of the impact of dietary intakes in human pregnancy on infant birthweight. Nutrients 7, 153-178.

12. Darnton-Hill I (2012) Global burden and significance of multiple micronutrient deficiencies in pregnancy. Nestlé Nutr Inst Work 70, 49-60.

13. Kiboi W, Kimiywe J \& Chege P (2016) Dietary diversity, nutrient intake and nutritional status among pregnant. Int $J$ Health Sci Res 6, 378-385. 
14. Othoo DA, Waudo J \& Kuria EN (2014) Dietary assessment of vitamin $\mathrm{A}$ and iron among pregnant women at Ndhiwa sub-district hospital-Kenya. African J Food Agric Nutr Dev 14, 2114-2128.

15. Smith V (2014) Multiple-micronutrient supplementation for women during pregnancy. In Bhutta ZA, editor. Pract Midwife [Internet], vol. 17, pp. 36-38. Available at http://doi.wiley.com/ 10.1002/14651858.CD004905.pub4 [cited 17 April 2019].

16. Waweru J, Mugenda O \& Kuria E (2011) Anaemia in the context of pregnancy and HIV/AIDS: a case of Pumwani Maternity Hospital in Nairobi, Kenya. African J Food Agric Nutr Dev 9, 748-763.

17. Mwaniki N, Chege PM \& Munyaka A (2019) Dietary diversity, iron intake and anemia among pregnant women in Embu county, Kenya. Nutr Technol 5, 6-11.

18. Nunn RL, Kehoe SH, Chopra H, et al. (2019) Dietary micronutrient intakes among women of reproductive age in Mumbai slums. Eur J Clin Nutr 73, 1536-1545. doi:10.1038/s41430-019-0429-6.

19. Hossain B, Sarwar T, Reja S, et al. (2013) Nutritional status of pregnant women in selected rural and urban area of Bangladesh. J Nutr Food Sci 03, 1-3.

20. Milman N (2019) Dietary iron intake in women of reproductive age in Europe: a review of 49 studies from 29 countries in the period 1993-2015. J Nutr Metab 2019, 1-13.

21. Ma Q, Kim E, Lindsay EA, et al. (2012) Dose-dependent manner in human intestinal Caco-2 cells. J Food Sci 76, 1-19.

22. Gulec S, Anderson GJ \& Collins JF (2014) Mechanistic and regulatory aspects of intestinal iron absorption. Am J Physiol Liver Physiol 307, G397-G409.

23. Péneau S, Dauchet L, Vergnaud AC, et al. (2008) Relationship between iron status and dietary fruit and vegetables based on their vitamin C and fiber content. Am I Clin Nutr 87, 1298-1305.

24. Kaufman C (2018) Foods to fight iron deficiency [Internet]. Academy of Nutrition and Diabetics. Available at https://www.eatright.org/ health/wellness/preventing-illness/iron-deficiency [cited 17 June 2019].

25. Chepchirchir M (2020) Best fruits to grow in Kenya [Internet]. Mt. KenyaTimes. Available at https://www.mtkenyatimes.co.ke/bestfruits-to-grow-in-kenya/ [cited 17 April 2020].

26. Tropical Sky. A true taste of Kenya | Kenya, Africa travel inspiration - tropical Sky [Internet]. Tropical Sky. Available at https:// www.tropicalsky.co.uk/africa-holidays/kenya/a-true-taste-of-kenya [cited 17 April 2020].

27. Gudrun BK, Kehlenbeck K \& McMullin S (2015) Fruit consumption and production: habits, preferences and attitudes of rural households in western Kenya. Poster [Internet], p. 2. Available at https:// cgspace.cgiar.org/bitstream/handle/10568/67190/Keding et al. Poster HHC2015 FINAL.pdf?sequence=1 [cited 17 April 2020].

28. Waweru JM (2011) Iron status and HIV/AIDS: a case of pregnant women at Pumwani Maternity Hospital in Nairobi, Kenya (Master's Thesis, Kenyatta University, Nairobi, Kenya) [nternet]. Available at https://ir-library.ku.ac.ke/handle/123456789/2027 [cited 17 April 2019].

29. Kehoe SH, Dhurde V, Bhaise S, et al. (2019) Barriers and facilitators to fruit and vegetable consumption Among rural Indian women of reproductive age. Food Nutr Bull 40, 87-98.

30. Weldekidan F, Kote M, Girma M, et al. (2018) Determinants of anemia among pregnant women attending antenatal clinic in public health facilities at Durame town: unmatched case control study. Anemia 2018, 1-8.

31. Mugenda OM \& Mugenda AG (2003) Research methods: sample size determination. African Centre for Technology Studies.
32. Namaste SM, Rohner F, Huang J, et al. (2017) Adjusting ferritin concentrations for inflammation: Biomarkers Reflecting Inflammation and Nutritional Determinants of Anemia (BRINDA) project. Am J Clin Nutr 106, 359S-371S.

33. WHO (2020) WHO guideline on use of ferritin concentrations to assess iron status in individuals and populations, World Health Organization, Geneva, 15-17.

34. de la Cruz-Góngora V, Villalpando S \& Shamah-Levy T (2018) Prevalence of anemia and consumption of iron-rich food groups in Mexican children and adolescents: Ensanut MC 2016. Salud Publica Mex 60, 291-300.

35. Beck KL, Conlon CA, Kruger R, et al. (2014) Dietary determinants of and possible solutions to iron deficiency for young women living in industrialized countries: a review. Nutrients $\mathbf{6}$, 3747-3776.

36. Cade JE, Moreton JA, O'Hara B, et al. (2005) Diet and genetic factors associated with iron status in middle-aged women. $A m J$ Clin Nutr 82, 813-820.

37. Pynaert I, De Bacquer D, Matthys C, et al. (2009) Determinants of ferritin and soluble transferrin receptors as iron status parameters in young adult women. Public Health Nutr 12, 1775-1782.

38. Leonard AJ, Chalmers KA, Collins CE, et al. (2014) The effect of nutrition knowledge and dietary iron intake on iron status in young women. Appetite 81, 225-231.

39. Blanco-Rojo R, Toxqui L, López-Parra AM, et al. (2014) Influence of diet, menstruation and genetic factors on iron status: a crosssectional study in Spanish women of childbearing age. Int J Mol Sci 15, 4077-4087.

40. Rigas AS, Sørensen CJ, Pedersen OB, et al. (2014) Predictors of iron levels in 14,737 Danish blood donors: results from the Danish blood donor study. Transfusion 54, 789-796.

41. Ruston D, Hoare J, Henderson L, et al. (2004) The national diet \& nutrition survey: adults aged 19 to 64 years. Natl Diet Nutr Surv $\mathbf{4}$, $15-16$.

42. Cercamondi CI, Egli IM, Zeder C, et al. (2014) Sodium iron EDTA and ascorbic acid, but not polyphenol oxidase treatment, counteract the strong inhibitory effect of polyphenols from brown sorghum on the absorption of fortification iron in young women. Br J Nutr 111, 481-489. doi:10.1017/S0007114513002705

43. Dasa F \& Abera T (2018) Factors affecting iron absorption and mitigation mechanisms: a review. Int J Agric Sci Food Technol 4, 24-30.

44. Black AK, Backstrand JR, Allen LH, et al. (2002) Diet and iron status of nonpregnant women in rural central Mexico. Am J Clin Nutr 76, 156-164.

45. Ghatpande NS, Apte PP, Naik SS, et al. (2019) Fruit and vegetable consumption and their association with the indicators of iron and inflammation status among adolescent girls. J Am Coll Nutr 38, 218-226.

46. Ghose B \& Yaya S (2018) Fruit and vegetable consumption and anemia among adult non-pregnant women: Ghana demographic and health survey. PeerJ 2018, 1-16.

47. Asakura K, Sasaki S, Murakami K, et al. (2009) Iron intake does not significantly correlate with iron deficiency among young Japanese women: a cross-sectional study. Public Health Nutr 12, 1373-1383.

48. Blanco-Rojo R, Baeza-Richer C, Lápez-Parra AM, et al. (2011) Four variants in transferrin and HFE genes as potential markers of iron deficiency anaemia risk: an association study in menstruating women. Nutr Metab 8, 1-8. 